\title{
The accuracy of calculating form deviations of selected free-form surfaces
}

\author{
Dokładność obliczania odchyłek kształtu \\ wybranych powierzchni swobodnych
} MAREK MAGDZIAK
ANDRZEJ KAWALEC *

The possible reason for the incorrect form deviations calculated using an algorithm available in the selected software of coordinate measuring machine was identified. This method is available in the Calypso software and it is based on local deviations calculated at nominal points. The analysis was made for the selected examples of free-form surfaces. There are presented the results of numerical investigations based on simulations of coordinate measurements of selected object. The measured points were generated with assumed values of scatter in relation to the nominal profiles of the analyzed product. The simulations were made using 3 selected methods for computing the form deviations and various distances between the measured points. In order to verify the results of simulation studies there were made experimental investigations. The experimental investigations were done using selected coordinate measuring system and chosen measurement parameters. The results of performed measurements confirm the simulation results.

KEYWORDS: coordinate measuring technique, free-form surface, form deviation

Wskazano możliwa przyczynę błędów w obliczaniu odchyłek kształtu z wykorzystaniem algorytmu wybranego oprogramowania współrzędnościowej maszyny pomiarowej. Metoda ta jest dostępna w oprogramowaniu Calypso i bazuje na lokalnych odchyłkach kształtu obliczanych w punktach nominalnych. Analiza została przeprowadzona dla wybranych przykładów powierzchni swobodnych. Przedstawiono wyniki badań numerycznych, które polegały na symulacjach pomiarów współrzędnościowych wybranego przedmiotu. Punkty pomiarowe były generowane z określonymi wartościami rozrzutów względem profili nominalnych analizowanego wyrobu. Symulacje zrealizowano z użyciem 3 wybranych metod obliczania odchyłek kształtu oraz różnych odległości między punktami pomiarowymi. W celu weryfikacji wyników badań symulacyjnych przeprowadzono badania doświadczalne. Badania eksperymentalne zrealizowano z użyciem wybranego współrzędnościowego systemu pomiarowego oraz wybranych parametrów pomiaru. Wyniki pomiarów potwierdzają rezultaty symulacji.

SŁOWA KLUCZOWE: współrzędnościowa technika pomiarowa, powierzchnia swobodna, odchyłka kształtu

Products made of free-form surfaces are used, among others, in aeronautical, transport and shipbuilding industries. Those products may be measured using, e.g. coordinate measuring machines [1,2]. The software developed for coordinate measuring systems contains several algorithms which enable among other things computing the form deviations of measured products. In the case of Calypso software made by the Carl Zeiss company there

\footnotetext{
* Dr inż. Marek Magdziak (marekm@prz.edu.pl), dr hab. inż. Andrzej Ka walec (ak@prz.edu.pl) - Katedra Technik Wytwarzania i Automatyzacji, Wydział Budowy Maszyn i Lotnictwa Politechniki Rzeszowskiej
}

\author{
DOI: https://doi.org/10.17814/mechanik.2017.11.172
}

is the possibility to verify the accuracy of manufacturing of particular product containing both free-form surfaces and regular geometric shapes by using the following methods [3]:

- a deviation in a nominal vector direction - local deviations are measured at nominal points in the direction of normal vector up to the intersection with an actual curve, which represents a real shape of a measured object. This method is denoted in the following sections with symbol $N$; - an actual-nominal deviation - local deviations are measured at measured points as distances between an actual curve and a nominal curve. This method is denoted in the following sections with symbol $R$;

- a space point evaluation - a form deviation with a space point evaluation is the distance between a nominal point and the intersection with a measuring curve. A measuring curve represents indicated measured points. In the next step of form deviation evaluation the measured distance is corrected by a stylus radius. The described algorithm can be implemented in the case of measurement element 2D curve, which is the part of Calypso measurement software; - a deviation in grid coordinates - in order to calculate a deviation in grid coordinates the nominal vector from a nominal point to the intersection with an actual curve is divided into the components, which are parallel to grid coordinate axes. The form deviation is the length of large component. The method can be also implemented in the case of measurement element 2D curve in the Calypso measurement software

- a radial deviation - a deviation is calculated radially from a reference point as the distance between a nominal point and an actual curve. The method can be implemented when using the measurement element 2D curve;

- a space point evaluation - in the last method the closest indicated measured point is searched for each nominal point. The found point is then corrected by a stylus radius in a nominal vector direction. The corrected measured point is projected on a nominal vector. The distance between a projected measured point and a nominal one is output as a form deviation. The last algorithm does not use an interpolation process of measured points.

Moreover, in paper [4] there was proposed a method for computing the form deviations of curvilinear surfaces of products which considers the Lagrange and Tschebyschev interpolation of corrected measured points. That method is denoted in the following sections of the paper with symbol $L-C$. In the case of that method the measured points are divided into several groups containing 5 points each. Each group of points is interpolated with fourth degree polynomials using the above mentioned interpolation methods. In the next step there are computed local deviations associated with the distances between nominal points and the curves representing real shape of measured object. The form deviation is computed based on the local deviations. 
In the next section of the paper there are presented the results of numerical investigations. The aim of the investigations was comparison of selected methods for computing form deviations. There are compared the results obtained using methods available in considered measurement software ( $N$ and $R$ ) and the method based on the interpolation of measured points $(L-C)$. Based on obtained results of numerical investigations there is indicated one potential reason for incorrect computations of form deviations using the method $N$, which is available in the Calypso software. Moreover, there are presented the results of experimental investigations which confirm the results of made simulations. The last part of the paper contains conclusions following the investigations.

\section{Numerical investigations}

Numerical investigations were done using the Calypso software which has the ability to work in simulation mode. Simulation research concerned the coordinate measurements of selected product (fig. 1). Simulations were made using the methods for computing of form deviations which base on local deviations checked at nominal points $(N)$ and measured points $(R)$ as well as on the interpolation of corrected measured points $(L-C)$. The 2 first methods are available in the Calypso software. In the case of the last method, in order to calculate the form deviation there was used the Lagrange interpolation of measured points. The selection of interpolation method was the effect of performed statistical analysis of the results of coordinate measurements' simulations. The results of the analysis are presented in paper [4]. Moreover, investigations were made for various values of dispersion of measured points $( \pm 0.05 \mathrm{~mm}$ and $\pm 0.1 \mathrm{~mm}$ ) with regard to nominal profiles and for various distances between the measured points ( $0.1 \mathrm{~mm} ; 0.25 \mathrm{~mm} ; 0.5 \mathrm{~mm} ; 0.75 \mathrm{~mm}$ and $1 \mathrm{~mm}$ ). Dispersion defines the area around a nominal profile in which considered points are generated.

The results of simulations of coordinate measurements are presented in the table. The results concern the values of form deviations of curvilinear profiles obtained for various parameters of simulation in the case of measurements concerning the surfaces denoted S1 54 (fig.1). The values of form deviations should be 2 times bigger than the assumed values of scatter of measured points.

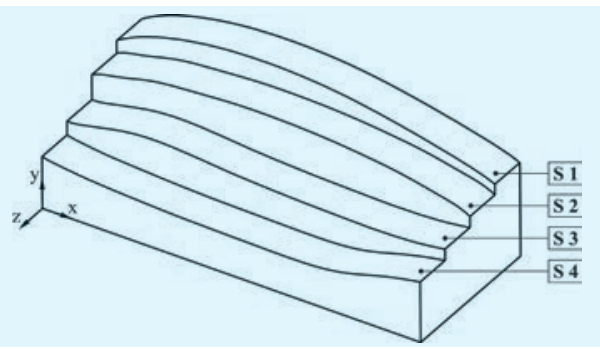

Fig. 1. Product used for simulation investigations

Based on obtained results of numerical investigations in the case of method $N$ there was found that the values of form deviations were bigger than the assumed values of scatter of measured points. Analogous results of research were obtained in the case of measurements' simulations of other objects. The results are presented in paper [4]. It may be associated with incorrect calculation of curves representing the shape of measured object.

In fig. 2 there are presented faulty segments of measured curves of analyzed object which were obtained for selected parameters of simulations of coordinate meas-
TABLE. The results of numerical investigations

\begin{tabular}{|c|c|c|c|}
\hline \multicolumn{4}{|c|}{ Dispersion $= \pm 0.05 \mathrm{~mm}$, distance $=0.1 \mathrm{~mm}$} \\
\hline$S$ & $\mathrm{~N}, \mathrm{~mm}$ & $R, \mathrm{~mm}$ & $L-C, \mathrm{~mm}$ \\
\hline 1 & 0.1167 & 0.1000 & 0.1292 \\
\hline 2 & 0.1052 & 0.1000 & 0.1288 \\
\hline 3 & 0.1030 & 0.0999 & 0.1542 \\
\hline 4 & 0.1035 & 0.1000 & 0.1515 \\
\hline \multicolumn{4}{|c|}{ Dispersion $= \pm 0.05 \mathrm{~mm}$, distance $=0.25 \mathrm{~mm}$} \\
\hline$S$ & $\mathrm{~N}, \mathrm{~mm}$ & $R, \mathrm{~mm}$ & $L-C, \mathrm{~mm}$ \\
\hline 1 & 0.1323 & 0.0997 & 0.1355 \\
\hline 2 & 0.1637 & 0.0999 & 0.1386 \\
\hline 3 & 0.1301 & 0.0998 & 0.1399 \\
\hline 4 & 0.2234 & 0.1000 & 0.1665 \\
\hline \multicolumn{4}{|c|}{ Dispersion $= \pm 0.05 \mathrm{~mm}$, distance $=0.5 \mathrm{~mm}$} \\
\hline$S$ & $\mathrm{~N}, \mathrm{~mm}$ & $R, \mathrm{~mm}$ & $L-C, \mathrm{~mm}$ \\
\hline 1 & 0.4660 & 0.0995 & 0.1382 \\
\hline 2 & 0.6917 & 0.0994 & 0.1455 \\
\hline 3 & 0.5851 & 0.0999 & 0.1318 \\
\hline 4 & 0.3349 & 0.0998 & 0.1109 \\
\hline \multicolumn{4}{|c|}{ Dispersion $= \pm 0.05 \mathrm{~mm}$, distance $=0.75 \mathrm{~mm}$} \\
\hline$S$ & $\mathrm{~N}, \mathrm{~mm}$ & $R, \mathrm{~mm}$ & $L-C, \mathrm{~mm}$ \\
\hline 1 & 0.7186 & 0.0998 & 0.1301 \\
\hline 2 & 1.5306 & 0.0993 & 0.1070 \\
\hline 3 & 1.0533 & 0.0991 & 0.1378 \\
\hline 4 & 0.8301 & 0.0978 & 0.1360 \\
\hline \multicolumn{4}{|c|}{ Dispersion $= \pm 0.05 \mathrm{~mm}$, distance $=1 \mathrm{~mm}$} \\
\hline$S$ & $\mathrm{~N}, \mathrm{~mm}$ & $R, \mathrm{~mm}$ & $L-C, \mathrm{~mm}$ \\
\hline 1 & 1.2847 & 0.1000 & 0.1462 \\
\hline 2 & 2.4028 & 0.0987 & 0.1282 \\
\hline 3 & 1.7421 & 0.0992 & 0.1320 \\
\hline 4 & 1.1747 & 0.0998 & 0.1067 \\
\hline \multicolumn{4}{|c|}{ Dispersion $= \pm 0.1 \mathrm{~mm}$, distance $=0.1 \mathrm{~mm}$} \\
\hline$S$ & $\mathrm{~N}, \mathrm{~mm}$ & $R, \mathrm{~mm}$ & $L-C, \mathrm{~mm}$ \\
\hline 1 & 0.2195 & 0.2000 & 0.2942 \\
\hline 2 & 0.2217 & 0.1999 & 0.3012 \\
\hline 3 & 0.2114 & 0.1998 & 0.3492 \\
\hline 4 & 0.1940 & 0.1998 & 0.2765 \\
\hline \multicolumn{4}{|c|}{ Dispersion $= \pm 0.1 \mathrm{~mm}$, distance $=0.25 \mathrm{~mm}$} \\
\hline$S$ & $\mathrm{~N}, \mathrm{~mm}$ & $R, \mathrm{~mm}$ & $L-C, \mathrm{~mm}$ \\
\hline 1 & 0.1978 & 0.1993 & 0.2372 \\
\hline 2 & 0.3432 & 0.1991 & 0.2299 \\
\hline 3 & 0.3724 & 0.1996 & 0.2604 \\
\hline 4 & 0.2019 & 0.1980 & 0.2875 \\
\hline \multicolumn{4}{|c|}{ Dispersion $= \pm 0.1 \mathrm{~mm}$, distance $=0.5 \mathrm{~mm}$} \\
\hline$S$ & $\mathrm{~N}, \mathrm{~mm}$ & $R, \mathrm{~mm}$ & $L-C, \mathrm{~mm}$ \\
\hline 1 & 0.5001 & 0.1976 & 0.2659 \\
\hline 2 & 0.9090 & 0.1982 & 0.2461 \\
\hline 3 & 0.3573 & 0.1996 & 0.2728 \\
\hline 4 & 0.2199 & 0.1987 & 0.2889 \\
\hline \multicolumn{4}{|c|}{ Dispersion $= \pm 0.1 \mathrm{~mm}$, distance $=0.75 \mathrm{~mm}$} \\
\hline$S$ & $\mathrm{~N}, \mathrm{~mm}$ & $R, \mathrm{~mm}$ & $L-C, \mathrm{~mm}$ \\
\hline 1 & 0.6699 & 0.1996 & 0.3472 \\
\hline 2 & 1.3126 & 0.1982 & 0.2527 \\
\hline 3 & 1.1054 & 0.1987 & 0.3112 \\
\hline 4 & 0.8439 & 0.1993 & 0.2633 \\
\hline \multicolumn{4}{|c|}{ Dispersion $= \pm 0.1 \mathrm{~mm}$, distance $=1 \mathrm{~mm}$} \\
\hline$S$ & $\mathrm{~N}, \mathrm{~mm}$ & $R, \mathrm{~mm}$ & $L-C, \mathrm{~mm}$ \\
\hline 1 & 1.4855 & 0.1976 & 0.2573 \\
\hline 2 & 2.5767 & 0.1968 & 0.2697 \\
\hline 3 & 1.7077 & 0.1982 & 0.2635 \\
\hline 4 & 1.1402 & 0.1981 & 0.2502 \\
\hline
\end{tabular}

urements. Those curves were obtained in result of application of the method $N$ based on computing form deviations using the local deviations measured at nominal points. The measured curves have shapes significantly different from the nominal profiles along their starting segments.

\section{Experimental investigations}

In order to verify the results of numerical studies the experimental investigations were made. Experiments were done using the coordinate measurement machine ACCURA II equipped with the measuring probe VAST XT which cooperates with the Calypso software. For the purpose of coordinate measurements of free-form surfaces there was used the measurement element 2D curve. The values of parameters, whose meaning is explained in $[5,6]$, describing the accuracy of the applied measuring system are the following: 


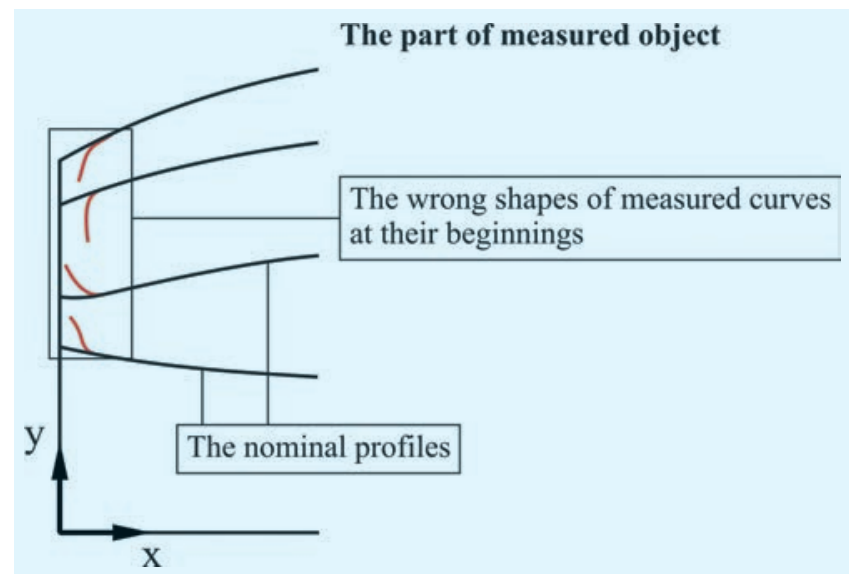

Fig. 2. The curves representing the measured object which were obtained in result of application of the method $N$ and selected parameters of simulation

- $E_{\mathrm{L}, \mathrm{MPE}}=1.6+\mathrm{L} / 333 \mu \mathrm{m}$;

- $P_{\mathrm{FTU}, \mathrm{MPE}}=1.7 \mu \mathrm{m}$;

- $M P E_{\mathrm{Tij}}=2.5 \mu \mathrm{m}$;

- $M P T_{\text {Tij }}=50.0 \mathrm{~s}$.

The measurements were done for the surfaces $S 1 \div S 4$ (fig. 1) and the distance between measured points $1.0 \mathrm{~mm}$. There were applied 2 measurement velocities: $10 \mathrm{~mm} / \mathrm{s}$ and $30 \mathrm{~mm} / \mathrm{s}$. The time of masking of measured points after starting of scanning was $0.25 \mathrm{~s}$. Selected results of coordinate measurements are shown in figs. 3 and 4 . The results are presented in the form of measured curves, which were obtained using the methods $N$ and $R$ of calculating form deviations.

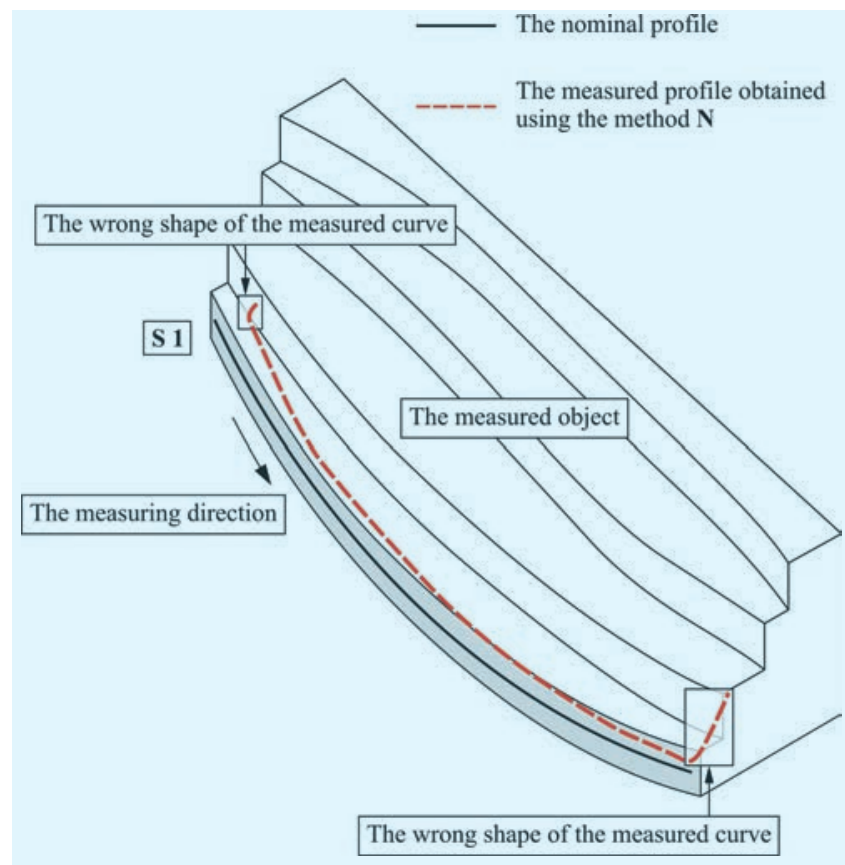

Fig. 3. The nominal and measured curves obtained using the method $N$ in the case of measurement of the surface $S 1$ with the scanning velocity $10 \mathrm{~mm} / \mathrm{s}$ (magnification 100)

\section{Conclusions}

On the grounds of the analysis of results of numerical investigations there were observed faulty values of form deviations calculated using the method available in the Calypso software which is based on local deviations at nominal points $(N)$. Obtained values of form deviations, significantly different from the assumed values of scatter

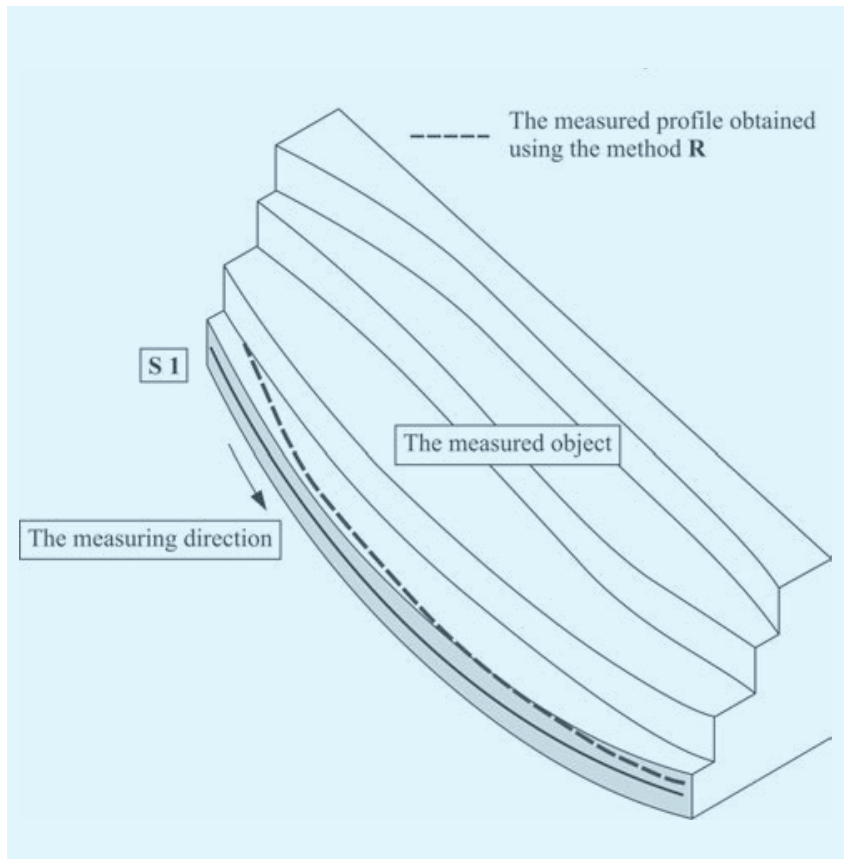

Fig. 4. The nominal and measured curves obtained using the method $R$ in the case of measurement of the surface $S 1$ with the scanning velocity $10 \mathrm{~mm} / \mathrm{s}$ (magnification 100)

of measured points, are associated with faulty shapes of measured curves, especially in the regions of starting nominal points of considered surfaces (fig. 2).

The results of experimental investigations confirm the results of performed simulations of coordinate measurements. The measured curves approximating measured points and obtained using the method $N$ differ from the curves measured and computed applying the method $R$ (figs. 3 and 4). The differences of shapes of the analyzed curves are especially significant in the starting and ending regions of measured curvilinear surfaces. On the grounds of obtained results of measurements in the case of the starting regions it can be found that the extrapolation of measured curves performed by the Calypso software is done mistakenly due to the lack of measurement data. The absence of measurement data follows from application of the time of masking in the measurement procedure after the start of scanning.

Similar abnormality concerning the shapes of curves measured and calculated using the method $N$ was observed in the case of the majority of other considered surfaces and the scanning velocity $30 \mathrm{~mm} / \mathrm{s}$.

\section{REFERENCES}

1. Li Y., Peihua G. „Free-form surface inspection techniques state of the art review”. Computer-Aided Design. 36, 13 (2004): pp. 1395-1417.

2. Kawalec A., Magdziak M. „The selection of radius correction method in the case of coordinate measurements applicable for turbine blades". Precision Engineering. 49 (2017): pp. 243-252.

3. Calypso, Carl Zeiss, software documentation. Carl Zeiss Industrielle Messtechnik. Oberkochen, 2010.

4. Magdziak M. „An algorithm of form deviation calculation in coordinate measurements of free-form surfaces of products”. Strojniški vestnik Journal of Mechanical Engineering. 62, 1 (2016): pp. 51-59.

5. PN-EN ISO 10360-2:2010 Geometrical product specifications (GPS) - Acceptance and reverification tests for coordinate measuring machines (CMM) - Part 2: CMMs used for measuring linear dimensions.

6. PN-EN ISO 10360-4:2002 Geometrical product specifications (GPS) - Acceptance and reverification tests for coordinate measuring machines (CMM) - Part 4: CMMs used in scanning measuring mode. 